\title{
The influence of the vulnerability of sectors on their survival and probability of insolvency: the case of small and medium entities in Spain
}

\author{
SOMOZA, ANTONIO \\ Universidad de Barcelona \\ Correo electrónico: asomozal@ub.edu
}

\begin{abstract}
This paper looks at a sample of small and medium entities in Spain and analyzes the effect of the vulnerability of sectors to insolvency on their survival and the probability that they will go bankrupt. We collected data from solvent and insolvent firms in Spain over the period 2012-2016, and grouped them according to the percentage of insolvencies by sector (highest, lowest, and a reference group). The results show that no differences in the endurance of the firms emerge among the groups, while some variables appear to be relevant when the logit analysis is applied. Survival depends on liquidity and size in all industries, but profitability and turnover are also essential for the group with the highest levels of insolvency. The probability of bankruptcy is mainly explained by turnover and short-term solvency. Size and turnover have negative effects on bankruptcy. Age is also a common factor, but with a different interpretation for each technique. The main contribution of this paper is the analysis of insolvency in the two dimensions of survival and probability according to the sectorial insolvency rate.
\end{abstract}

Keywords: insolvency, bankrutpcy, survival, logit, Spain.

JEL classification: G33; M41; M21.

MSC2010: 62J12; 62N02; 62N03. 


\title{
La influencia de la vulnerabilidad de los sectores en su supervivencia y probabilidad de insolvencia: el caso de las pequeñas y medianas entidades en España
}

\begin{abstract}
RESUMEN
Este artículo analiza la vulnerabilidad sectorial a la insolvencia basándose en el análisis de supervivencia y la probabilidad de la misma en una muestra de pequeñas y medianas empresas en España. Se han recogido datos de empresas solventes e insolventes para el período 2012-2016 y han sido agrupadas por el porcentaje de insolvencias por sectores (alto, bajo y un grupo de referencia). Los resultados muestran que no hay diferencias en la duración de las empresas entre los grupos y algunas variables parecen ser relevantes cuando se aplica el análisis logístico. La supervivencia depende de la liquidez y el tamaño en todos los sectores, pero la rentabilidad y la rotación son también esenciales para el grupo con más altos niveles de insolvencia. La probabilidad de quiebra se explica principalmente por la rotación y la solvencia a corto plazo. El tamaño y la rotación tiene efectos negativos sobre la quiebra. La edad del negocio es también un factor común, pero con diferentes interpretaciones para cada técnica. La principal contribución del artículo reside en el análisis de la insolvencia en dos dimensiones: supervivencia y probabilidad de acuerdo con la tasa de insolvencia sectorial.
\end{abstract}

Palabras clave: insolvencia, quiebra, supervivencia, logit, España.

Clasificación JEL: G33; M41; M21.

MSC2010: 62J12; 62N02; 62N03.

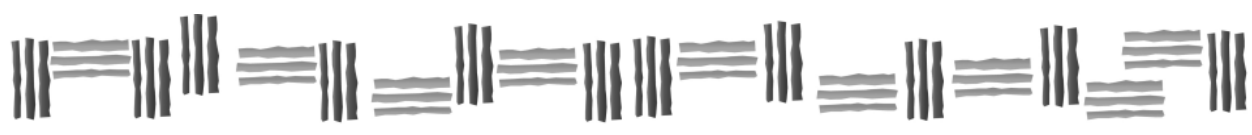




\section{Introduction.}

Credit risk and bankruptcy prediction research has been one of the main research topics in accounting and finance, and continues to attract the interest of academics and other practitioners.

The history and development of insolvency prediction models started in the 1960s with the wellknown works of Beaver (1966) and Altman (1968). Since then, an increasing number of studies of insolvency prediction models have appeared and this field of research has widened the scope of analysis and used various techniques (multiple discriminant analysis, logit, iterative partitioning, neuronal networks, among others).

Industry-wide distress can affect the insolvency of firms: firstly, by lowering the economic worth of the assets of the firm that has defaulted; and secondly, because the prices at which assets of insolvent firms can be sold depends on the financial condition of peer firms (competitors) (Shleifer \& Vishny, 1992). If default intensities are different across industries with otherwise identical firm-specific characteristics, it is of interest to investigate the determinants behind the effect on the industry.

The main objectives of this study are to analyze how the vulnerability of sectors (measured as the number of insolvencies over the number of existing firms) influences their survival and the probability of insolvency. Further, we wish to compare the explanatory variables from two points of view: technique and the criteria employed to create the groups. We try to answer the question of whether the explanatory variables are different if the sample used shows a high (or low) percentage of insolvent firms. At the same time, we seek to compare both techniques considering that they are different.

The contribution of this paper is twofold. On the one hand, it allows us to evaluate whether the risk to insolvency determines the survival of firms and the probability of bankruptcy. To our knowledge, this is the first study that compares samples in different sectors grouping them according to the risk of insolvency. On the other hand, it sheds light on the role that the explanatory variables play in these samples and on the results of the techniques.

The variables time and the probability differ according to the sector that is in distress, so the industry effect is significant for explaining survival. Moreover, the investigation of the outcome of insolvencies gives some additional insights: liquidity, profitability and size are determinants of the survival of firms. Additional factors such as return, short-term liquidity and turnover determine the probability.

The structure of the paper responds to the aim of the research. The first part is devoted to a revision of the literature, especially those contributions that consider sector variables. The following sections explain the process of sample selection and the choice of variables in the articles on this topic. The empirical sections analyze the data: firstly, in a descriptive way, secondly, through the survival models; and, finally, through the logit model.

\section{Background.}

The role of sector in insolvency probability has been extensively studied in the literature. The works of Edminster (1972), Platt and Platt (1991) and Mensah (1984) used variables adjusted by sector in order to compare the accuracy of the models with and without these adjustments and found that those with adjusted variables were better.

Subsequently, the industry effect on insolvency prediction has been analyzed as part of the explanatory variables and in order to test hypotheses. Lang and Stulz (1992), Shleifer and Vishny (1992), Opler and Titman (1994), Maksimovic and Philips (1997), and Berkovitch and Israel (1998) support the importance of industry effects on bankruptcy. A substantial body of research built models 
for a particular industry: banking (Brown \& Dinç 2011; Momparler, Carmona \& Climent, 2016; Iannota, Nocera \& Sironi, 2007; Rumler \& Waschiczek, 2016; Anchor, 2017; Petria, 2016; Bhimani, Gulamhussen \& Lopes, 2013; Soedarmono, Machrouh \& Tarazi, 2013); transport (Brozyna, Mentel \& Pisula, 2016); petroleum (Karan, Arslan \& Alatli, 2009); technology (Hsu, 2011; Huang, 2015), among others.

Although most of researchers have detected some influence of market structure on insolvency, Kennedy (2000) states that this effect is small. Chava and Jarrow (2004) highlight the reasons why the inclusion of sector variables can improve the models:

First, different industries face different levels of competition and, therefore, the likelihood of bankruptcy can differ for firms in different industries with otherwise identical balance sheets. Second, different industries may have different accounting conventions, again implying that the likelihood of bankruptcy can differ for firms in different industries with otherwise identical balance sheets. (p. 538)

The significance of industry as an important determinant of default risk is also put forward by Aertz and Pope (2013) who conclude that the changes in default risk always depend on global (but not national) factors and industry effects.

A number of studies compare the incidence of bankruptcy in different industries. For example, Berkovitch and Israel (1998) found that the proportion of firms that filed for bankruptcy is higher in mature industries as opposed to growth industries; Bunn and Redwood (2003), incorporating the macroeconomic effects into their model, showed that service firms have a lower probability of insolvency than the manufacturing sector.

Some authors include sectorial variables in a general model. For instance, Bhimani, Gulamhussen and Lopes (2010) revealed that industry and geographical variables influenced default for a sample of privately held Portuguese firms. Kaplan and Milton (2012) also applied three sectorial variables; and Huang and Lee (2013) used interaction terms between industry, firm size and competition intensity. Bhimani, Gulamhussen and Lopes (2013), using bank loan information to predict the timing of defaults, found that the incremental predictive ability of non-financial information surpassed that of macroeconomic and financial accounting information in the baseline, industry, and in- and out-of-the sample models. Laguillo (2016) also pointed out that the inclusion of qualitative sectorial variables improves the models and that general models (mixture of different sectors) are better than models focused on one industry.

The effect of concentration in industry has been the focus of several contributions. In general, the main conclusion is that industries that are more concentrated exhibit a higher probability of insolvency (Chiu, Pena \& Wang, 2013; Zhang, Altman \& Yen, 2010). Geopalan and Xie (2011) concluded that industries are more prone to distress if they have greater conglomeration. Along the same lines, Zhang (2013) found that competitors are affected more adversely if they are in industries that are more concentrated. Closely related to this, customer concentration (Irvine, Park \& Y1ldizhan, 2015; Chiu, Pena \& Wang, 2013; Huang \& Lee, 2013) produced contradictory results as Chiu, Pena and Wang (2013) pointed out that it did not affect failure probabilities (while Irvine, Park, \& Yildizhan (2015) provided confirmatory evidence). In a similar way, Maksimovic and Philips (1997) presented evidence that incidence of bankruptcy depends on industry demand conditions. The other side of the coin, competition, is another issue that has been studied. For example, Kanatas and Qui (2004) concluded that takeovers of distressed firms are related to the nature of product market competition. Soedarmono, Machrouh and Tarazi (2013) found that a higher degree of market power in the banking market is associated with higher insolvency risk of banks. 


\subsection{Insolvency models for Spain.}

In Spain different authors have extensively studied insolvency prediction over the last 30 years. Some authors have built a general model (Gabás, 1990; Gallego, Gómez \& Yañez, 1997; Liazarraga \& Archel, 1998, among others); others have focused on a single sector: banks (Laffarga, Martín, \& Vázquez, 1985, 1986, 1991, among others); insurance (López-Herrera Moreno, \& Rodríguez, 1994, Arellano, Gil, \& Martínez 2003); manufacturing (García, Calvo \& Arqués, 1997); other industries (textiles, Somoza 2001; hospitals, Bernal-Delgado, Campillo-Artero, \& García-Armesto, 2014). In some cases, the focus of interest has been the legal form of the entity (cooperatives, Masa, Iturrioz \& Martín, 2016; Iturrioz \& Martin 2013 in others), the comparison of different ways of bankruptcy resolution (López-Gutiérrez, Torre-Olmo, \& Sanfilippo-Azofra, 2011).

The use of different variables has also been analysed, especially cash flow (Gabás, 1990; Lizarraga, 1997; Lizarraga \& Archel, 1998; De Llano, Piñeiro \& Rodríguez, 2016; Rodríguez-López, Piñeiro \& de Llano, 2014; Rodríguez-Masero \& López-Manjón, 2016). A wide variety of techniques has been applied: for example, artificial neuronal nets (Serrano \& Martín, 1993) and iterative partitions (Gabás, 1990). Other investigations have focused on SMEs (Small and Medium Entities) (Van Hemmen, 1997; Lizarraga, 1997; Pozuelo, Labatut, \& Veres, 2013; Miranda, De la Torre \& Martínez, 2008). To our knowledge, however, the effect of the vulnerability of industry to insolvency has not been analyzed and this is the main contribution of this paper.

\section{Survival analysis.}

Survival analysis models the probability of a change in a dependent variable $Y$ from an origin state $j$ to a destination state $K$ due to casual factors (Bloosfeld \& Rohwer, 1995). The event failure time represents the duration of time until the dependent variable changes from state $j$ to state $k$. The focus is on the occurrence and timing of financial distress (LeClere, 2000, 2005).

The survival function gives the probability that a firm survives longer than some specified time $t$, namely, it gives the probability that the random variable $T$ exceeds the specified time of study $P(T>t)$ (1):

$$
S(t)=\mathrm{P}(T>t)
$$

It represents the probability that $T$ is greater than a value $t$ and indicates the survival time is longer than $t$.

The probability density function is defined as (2):

$$
f(t)=\lim _{\Delta t \rightarrow 0}\left(\frac{\mathrm{P}(\mathrm{t} \leq \mathrm{T}<\mathrm{t}+\Delta \mathrm{t} \mid T \geq t}{\Delta \mathrm{t}}\right)
$$

This function "gives insight into conditional failure rates; identifies the specific model form and mathematical model for survival analysis, and it is usually written in terms of this function" (Kleinbaum \& Klein, 2012, p. 45).

The Kaplan-Meier survival curves plot survival data. This survivor function, denoted by $S(t)$, gives the probability that the random variable $T$ exceeds the specified time. Theoretically, the survival function is a smooth curve which begins at $S(t)=1$ at $t=0$ and heads downward towards zero as $t$ increases towards infinity.

In this study, the Cox PH model has been used (equation 3). This model provides an expression for the hazard at the time $t$ for an individual with a given specification of a set of covariates. This is a 
semi-parametric model in which the hazard rate at time $t$ is the product of two functions, a baseline hazard function that is a function of $t$, but does not involve the predictors, and the exponential expression (3) that involves a set of covariates.

$$
h(t, X)=h_{o}(t) \exp \left(\beta_{1} X_{1}+\cdots+\beta_{p} X_{p}\right)
$$

where $X_{1}, X_{2}, \ldots, X_{p}$ are the vector of covariates.

The application of survival analysis to insolvency started with the works of Lane, Looney and Wansley (1986) in an accounting-related area and Kim, Anderson, Amburgey and Hickman (1995) in insolvencies. Since then, a great number of studies have applied it using this technique with different objectives.

\section{Sample.}

Given that the aim of this study is to analyze the influence of sector vulnerability on failure, the first step has been to select the sectors in which the number of insolvencies was the highest and the lowest.

According to statistics by the National Statistics Institute (Table 1), we can divide the industry population into three groups:

- those with the highest level of insolvencies: construction of buildings, wholesale trade (except of motor vehicles and motorcycles), and retail trade (except of motor vehicles and motorcycles).

- those with the lowest level of insolvencies: manufacture of computers, electronic and optical products; manufacture of electrical equipment; manufacture of machinery and equipment; manufacture of motor vehicles, trailers and semi-trailers; manufacture of other transport equipment; manufacture of furniture; other manufacturing; agriculture; energy.

- a reference group (that excludes the previous sectors). This is a sample of firms that did not belong to any of the previous sectors (the highest and the lowest levels of insolvencies).

Table 1. National statistics of the number of insolvencies by sector.

\begin{tabular}{|c|c|c|c|c|c|c|c|c|c|c|}
\hline INDUSTRIES (by year) & 2016 & $\%$ & 2015 & $\%$ & 2014 & $\%$ & 2013 & $\%$ & 2012 & $\%$ \\
\hline -Agriculture and fishing & 44 & 1 & 70 & 1 & 57 & 1 & 83 & 1 & 71 & 1 \\
\hline -Manufacturing and energy & 528 & 8 & 642 & 8 & 1023 & 10 & 1575 & 11 & 1531 & 11 \\
\hline - Manufacturing: intermediate goods & 207 & 3 & 218 & 3 & 365 & 4 & 623 & 4 & 597 & 4 \\
\hline - Manufacturing: capital goods & 104 & 2 & 139 & 2 & 241 & 2 & 385 & 3 & 448 & 3 \\
\hline goods & 42 & 1 & 51 & 1 & 90 & 1 & 141 & 1 & 150 & 1 \\
\hline consumer goods & 147 & 2 & 193 & 2 & 263 & 3 & 379 & 3 & 318 & 2 \\
\hline - $\quad$ Energy & 28 & 0 & 41 & 1 & 64 & 1 & 47 & 0 & 18 & 0 \\
\hline -Building & 782 & 12 & 1031 & 13 & 1511 & 15 & 2430 & 16 & 2487 & 18 \\
\hline - $\quad$ Houses & 522 & 8 & 723 & 9 & 1024 & 10 & 1591 & 11 & 1633 & 12 \\
\hline - Other & 260 & 4 & 308 & 4 & 487 & 5 & 839 & 6 & 854 & 6 \\
\hline -Commerce & 895 & 14 & 1100 & 14 & 1272 & 12 & 1687 & 11 & 1505 & 11 \\
\hline -Wholesale trade & 817 & 13 & 987 & 13 & 1115 & 11 & 1449 & 10 & 1330 & 10 \\
\hline -Retail & 78 & 1 & 113 & 1 & 157 & 2 & 238 & 2 & 175 & 1 \\
\hline
\end{tabular}




\begin{tabular}{lrrrrrrrrrr}
$\quad$-Transportation and logistics & 148 & 2 & 172 & 2 & 253 & 2 & 316 & 2 & 362 & 3 \\
-Catering & 277 & 4 & 302 & 4 & 369 & 4 & 400 & 3 & 277 & 2 \\
$\begin{array}{l}\text {-Information and communications } \\
\text {-Real estate, financials and insurance }\end{array}$ & 138 & 2 & 187 & 2 & 210 & 2 & 217 & 1 & 152 & 1 \\
$\begin{array}{l}\text {-Professional, scientific and technical } \\
\text { activities }\end{array}$ & 174 & 3 & 172 & 2 & 253 & 2 & 373 & 3 & 268 & 2 \\
$\begin{array}{l}\text {-Administrative activities and auxiliary } \\
\text { services. }\end{array}$ & 349 & 5 & 390 & 5 & 425 & 4 & 573 & 4 & 355 & 3 \\
-Other services & 230 & 4 & 222 & 3 & 284 & 3 & 455 & 3 & 287 & 2 \\
-No classification & 321 & 5 & 319 & 4 & 340 & 3 & 360 & 2 & 302 & 2 \\
TOTAL & 411 & 6 & 490 & 6 & 567 & 5 & 674 & 5 & 498 & 4 \\
& 6502 & 100 & 7870 & 100 & 0 & 100 & 5 & 0 & 13618 & 100 \\
\hline
\end{tabular}

Source: Instituto Nacional de Estadística (INE), 2017.

The next step was to look for the size of these firms. The Spanish statistics only depict turnover as an approximation to size. As we can see, bankruptcies were focused on the lowest values of turnover (Table 2).

Table 2. National statistics of the number of insolvent firms by turnover.

\begin{tabular}{lrrrrrrrrrr}
\hline $\begin{array}{l}\text { Turnover } \\
\text { (millions of euros) }\end{array}$ & 2016 & $\%$ & 2015 & $\%$ & 2014 & $\%$ & 2013 & $\%$ & 2012 & $\%$ \\
\hline Below 0.25 & 1618 & 38 & 1864 & 37 & 2319 & 35 & 2806 & 31 & 2322 & 26 \\
-From 0.5 to 1 & 484 & 11 & 593 & 12 & 680 & 10 & 1114 & 12 & 1218 & 13 \\
-From 0.25 to 0.5 & 514 & 12 & 589 & 12 & 724 & 11 & 987 & 11 & 1085 & 12 \\
-From 1 to 2 & 375 & 9 & 406 & 8 & 522 & 8 & 975 & 11 & 1060 & 12 \\
Below 2 & & & & & & & & & & \\
-From 2 to 5 & 256 & 6 & 316 & 6 & 404 & 6 & 809 & 9 & 949 & 10 \\
-From 5 to 10 & 90 & 2 & 118 & 2 & 170 & 3 & 342 & 4 & 375 & 4 \\
More than 10 & 72 & 2 & 87 & 2 & 126 & 2 & 293 & 3 & 306 & 3 \\
No classification & 888 & 21 & 1124 & 22 & 1619 & 25 & 1817 & 20 & 1724 & 19 \\
TOTAL & 4297 & 100 & 5097 & 100 & 6564 & 100 & 9143 & 100 & 9039 & 100 \\
\hline
\end{tabular}

Source: Instituto Nacional de Estadística (INE), 2017.

The sample is built by classifying the firms into one of the three groups and into the lowest of turnover values.

The pairing process consisted of matching one bankrupt firm with another in the same group that was solvent and had a similar turnover. The number of firms analyzed was 1164 for the sectors with the highest incidence of bankruptcy; 440 for those with the lowest rates of bankruptcy; and 2652 in the reference group (Table 3). 
Table 3. Impairment process and total sample.

\begin{tabular}{|l|r|r|r|r|r|r|r|r|}
\hline \multirow{2}{*}{$\begin{array}{c}\text { Number of firms with the } \\
\text { lowest turnover }\end{array}$} & \multicolumn{5}{|c|}{} & $\begin{array}{c}\text { SOLVENT } \\
\text { GROUP }\end{array}$ & TOTAL \\
\cline { 2 - 9 } & 2016 & 2015 & 2014 & 2013 & 2012 & TOTAL & TOTAL & \\
\hline $\begin{array}{l}\text { Highest } \\
\text { number of insolvencies }\end{array}$ & 147 & 95 & 82 & 54 & 17 & 582 & 582 & 1164 \\
\hline $\begin{array}{l}\text { Lowest } \\
\text { rates of insolvencies }\end{array}$ & 56 & 32 & 24 & 16 & 10 & 220 & 220 & 440 \\
\hline Reference group & 351 & 206 & 189 & 85 & 21 & 1281 & 1281 & 2562 \\
\hline Total & 554 & 333 & 295 & 155 & 48 & 2083 & 2083 & 4166 \\
\hline
\end{tabular}

Once the selection of the sample was made, we collected the financial variables in the SABI (Sistema de Análisis de Balances Ibéricos) database (Bureau van Dijk for Spain and Portugal) for the 10 years 2006-2016 in order to go back in time. We consider that the last year (year -1) was about 1213 months before the legal proceedings in order to avoid the last variables being biased by the event (as Ohlson, 1980, pointed out). In some cases, this last year was not available.

\section{Variables.}

The variables were chosen according to the previous literature and responds to the main features of a firm: solvency, leverage, profitability, liquidity and turnover were represented by one or more ratios as continuous variables (Table 4). When average measures were calculated, we considered two consecutive years.

The categorical variables are sector and age. Sector takes the value 0 if the firm belongs to one (or more) industries with the highest number of insolvencies and 1 if the firm operates in one (or more) industries with the lowest number of insolvencies. If the firm belongs to one (or more) industries in the reference group, then the variable is 2 .

Table 4. Selected ratios according to previous literature.

\begin{tabular}{|c|c|c|c|c|}
\hline Ratio & Calculation & Characteristic & Authors & $\begin{array}{l}\text { Expected sign } \\
\text { (insolvency) }\end{array}$ \\
\hline $\begin{array}{l}\text { WORKING CAPITAL/ } \\
\text { TOTAL ASSETS } \\
\text { (WC_TA) }\end{array}$ & $\begin{array}{l}\text { (current assets- } \\
\text { current liabilities)/ } \\
\text { total assets }\end{array}$ & SOLVENCY & $\begin{array}{l}\text { Chava \& Jarrow (2004) } \\
\text { Zhang, Altman \& Yen } \\
(2010)\end{array}$ & - \\
\hline $\begin{array}{l}\text { TOTAL LIABILITIES/ } \\
\text { TOTAL ASSETS } \\
\text { (TL_TA) }\end{array}$ & $\begin{array}{l}\text { (long-term debt }+ \\
\text { short-term debt)/total } \\
\text { assets }\end{array}$ & LEVERAGE & $\begin{array}{l}\text { Chava \& Jarrow (2004) } \\
\text { Hernández \& Wilson } \\
\text { (2013), Irvine, Park, \& } \\
\text { Yildizhan, (2015) (as } \\
\text { market value of total } \\
\text { assets), Huang \& Lee } \\
\text { (2013), Chiu, Pena, \& } \\
\text { Wang(2013) }\end{array}$ & + \\
\hline
\end{tabular}


SECTOR

RETURN ON
INVESTMENT (ROI)
RETURN ON EQUITY
(ROE)

RELATIVE SIZE

BITDA/

INTEREST

EXPENSES

(EBITDA_INT)

EBITDA/TOTAL

ASSETS

(EBITDA_TA)

CASH AND SHORTTERM ASSETS TO

MARKET VALUE OF

ASSETS (CASH_TA)

ASSET TURNOVER (TURNV)

AGE
0 : if the firm belongs

to the sectors with

the highest

percentage of

bankruptcies.

1: if the firm belongs

to the sector with the

lowest percentage of

bankruptcies.

2: if the firm belongs

to other sectors.

(net income+

financial expenses $\mathrm{x}$

(1- (tax

income/earnings

before tax))/average

total assets

Net income / average

of equity minus net

income

Log (total assets)

SIZE

Earnings before

interest and taxes

(EBITDA)/ financial

expenses

Earnings before interest and taxes/

total assets

(Cash+ short-term assets) / total assets

LIQUIDITY

FINANCIAL
COVERAGE

Hernández \& Wilson

(2013), Zhang (2010)

Chiu, Pena \&

Wang.(2013), Hernández

\& Wilson (2013), Huang

\& Lee (2013), James \&

Kizilaslan (2014)

PROFITABILITY James \& Kizilaslan (2014)

Sales / total assets

TURNOVER

$0=$ if the firm $\quad$ AGE

operates in the sector for less than 20

years.

$1=$ if the firm

operates in the sector for more than 20

years.
Chava \& Jarrow (2004), Irvine, Park, \& Y1ldizhan (2015)

Irvine, Park, \& Y1ldızhan (2015), Chiu, Pena \& Wang (2013)

Bhimani, Gulamhussen, \& Lopes (2013), Lukason, Laitinen, \& Suvas (2016)

Source: Own elaboration. 
Some other variables were rejected as the sample consisted of privately held companies not trading on the stock market (for instance, among others, market to book ratio).

In the case of age, the binary variable is 0 if the firm has less than 20 years of activity and 1 if greater. This choice responds to the fact that the number of insolvencies drops after 20 years of activity (Table 5): namely, that the insolvency focuses on the youngest firms. It is reasonable to think that the number of years is a positive factor in relation to survival, in line with previous literature.

Table 5. Insolvency rates according to years of activity.

\begin{tabular}{|l|r|r|r|r|r|r|r|r|r|r|}
\hline Number of years of activity & 2016 & $\%$ & 2015 & $\%$ & 2014 & $\%$ & 2013 & $\%$ & 2012 & $\%$ \\
\hline$\%$ Below 4 & & & & & & & & & & \\
\hline From 5 to 8 & 768 & 18 & 802 & 16 & 803 & 12 & 1074 & 12 & 848 & 10 \\
\hline From 9 to 12 & 767 & 18 & 892 & 18 & 1272 & 19 & 1892 & 21 & 1885 & 22 \\
\hline From 13 to 16 & 830 & 19 & 1001 & 20 & 1249 & 19 & 1598 & 17 & 1354 & 16 \\
\hline From 17 to 19 & 521 & 12 & 725 & 14 & 924 & 14 & 1233 & 13 & 1063 & 12 \\
\hline Below 20 years & 330 & 8 & 387 & 8 & 560 & 9 & 797 & 9 & 1302 & 15 \\
\hline 20 or more & 3216 & 75 & 3807 & 75 & 4808 & 73 & 6594 & 72 & 6452 & 75 \\
\hline No classification & 959 & 22 & 1137 & 22 & 1579 & 24 & 2310 & 25 & 1945 & 23 \\
\hline TOTAL & 122 & 3 & 153 & 3 & 177 & 3 & 239 & 3 & 184 & 2 \\
\hline
\end{tabular}

Source: Own elaboration.

\section{Descriptive results.}

The descriptive analysis has been made according to the final situation of the firm (solvent $v s$. bankrupt), sector and age. It is based on the average of available ratios for each firm and winsorizing each variable at $99 \%$ (in general, most of the firms for the solvent group showed available data for 10 years; however, most of the firms for the insolvent group only showed available data for 5 years).

The solvent firms (Table 6) exhibit the highest values of short-term solvency (WC_TA, .0890877), return (ROI, .0681726; ROE, .3873298, and EBITDA_TA .0307027), asset size (LOGTA, 7.555586); liquidity (CASH_TA, .3877141); turnover (TURNV, 1.503377), and financial coverage (EBITDA_INT, 1987.07). Insolvent firms show a higher level of indebtedness (TD_TA, 1.039512).

Table 6. Descriptive analysis according to financial situation.

\begin{tabular}{|l|c|c|c|c|c|c|c|c|}
\hline & \multicolumn{4}{|c|}{ Solvent group } & \multicolumn{3}{c|}{ Insolvent group } \\
\hline & Obs & Mean & Median & Std. Dev. & Obs & Mean & Median & Std. Dev. \\
\hline \multirow{2}{*}{$\begin{array}{l}\text { WC_TA } \\
\text { TD_TA } \\
\text { ROI }\end{array}$} & 1974 & .0890877 & .1607994 & .680998 & 1987 & -.2036494 & -.0020111 & .9817387 \\
\cline { 2 - 9 } & 1786 & .6959119 & .6961837 & .464377 & 1798 & 1.039512 & .9014694 & .7101794 \\
\cline { 2 - 9 } $\begin{array}{l}\text { LOGTA } \\
\text { EBITDA_INT }\end{array}$ & 1887 & .0681726 & .0488757 & .1344187 & 1663 & -.0112375 & .0131441 & .1355322 \\
\cline { 2 - 9 } & 1974 & 7.555586 & 7.170401 & 1.828494 & 1986 & 6.512614 & 6.378255 & 1.640026 \\
\cline { 2 - 9 } & 1949 & 1987.07 & 8.056549 & 13643.09 & 1958 & 8.815107 & .0697433 & 5921.84 \\
\cline { 2 - 9 } & 1973 & .0307027 & .05134 & .2261069 & 1982 & -.0967396 & -.0046522 & .3283919 \\
\hline
\end{tabular}




\begin{tabular}{|l|c|c|c|c|c|c|c|c|}
\cline { 2 - 8 } $\begin{array}{l}\text { CASH_TA } \\
\text { TURNV }\end{array}$ & 1969 & .3877141 & .3022612 & .3271098 & 1967 & .2387294 & .1433063 & .2602881 \\
\cline { 2 - 8 } & 1974 & 1.503377 & 1.058445 & 1.711 .722 & 1968 & 1.304126 & .9091041 & 1.523722 \\
\cline { 2 - 8 } & 1968 & 3873298 & .0858454 & 3.822821 & 1980 & -.5158398 & -.0553598 & 3.819109 \\
\hline
\end{tabular}

Source: Own elaboration.

The next step was to compare the three groups: the group with the highest number of insolvencies (Table 7) also exhibits the highest values of short-term solvency (working capital to total assets, .005113), indebtedness (.9009945), return (ROI, .0320139; EBITDA_TA, -.0178969), and turnover (1.567199). In contrast, the group with the lowest number of insolvencies (sector 1) exhibits the highest asset (LOGTA, 7.513352); ROE (.2194906), and EBITDA_INT (1118.37). The reference group (number 2) shows the best liquidity (CASH_TA: .3195494).

Table 7. Descriptive analysis by group.

\begin{tabular}{|c|c|c|c|c|c|c|c|c|c|c|c|c|}
\hline & \multicolumn{4}{|c|}{ Group 0} & \multicolumn{4}{|c|}{ Group 1} & \multicolumn{4}{|c|}{ Group 2} \\
\hline & Obs & Mean & Median & Std. Dev. & Obs & Mean & Median & Std. Dev. & Obs & Mean & Median & Std. Dev. \\
\hline WC_TA & 1150 & .005113 & .1973231 & 1.008429 & 228 & .0016733 & .0978015 & .5859262 & 2583 & -.0910003 & .0525476 & .8016716 \\
\hline TD_TA & 1036 & .9009945 & 0.8361676 & .6324804 & 215 & .7850464 & .7481284 & .6099476 & 2333 & .861434 & .796826 & .6214708 \\
\hline ROI & 1052 & .0320139 & 0.028816 & .1193275 & 192 & .0197147 & .0240562 & .1314949 & 2306 & .0314353 & .031377 & .1500351 \\
\hline LOGTA & 1150 & 7.143599 & 6.899671 & 1.85443 & 227 & 7.513352 & 7.423715 & 1.614065 & 2583 & 6.940809 & 6.686921 & 1.801965 \\
\hline EBITDA_INT & 1133 & 771.3991 & 1.44972 & 10488.39 & 227 & 738.2079 & 1.282386 & 7383.131 & 2547 & 1118.371 & 2.174304 & 10820.3 \\
\hline EBITDA_TA & 1147 & -.0178969 & 0.0200264 & .2526167 & 226 & -.032581 & .0126915 & .2455823 & 2582 & -.0399963 & .0226685 & .3071026 \\
\hline CASH_TA & 1146 & .3130887 & 0.0753719 & .3256681 & 226 & .2427676 & .157439 & .2260284 & 2564 & .3195494 & .2295321 & .3005116 \\
\hline TURNV & 1134 & 1.567199 & 1.04555 & 1.81027 & 225 & 697641 & .4760755 & .7761402 & 2583 & 1.393733 & 1.005059 & 1.573926 \\
\hline ROE & 1146 & -.1554564 & 0.0254128 & 4.149641 & 225 & .2194906 & -.0015 & 2.688422 & 2577 & -.0505744 & .028012 & 3.792574 \\
\hline
\end{tabular}

Group 0: the industries with the highest level of insolvencies. Group 1: the industries with the lowest level of insolvencies. Group 2: reference group.

Source: Own elaboration.

Regarding the effect of age, the firms with fewer than 20 years of activity (Table 8) show the highest values of indebtedness (TD_TA: .9742124), liquidity (CASH_TA: .3514962), and turnover (TURNV: 1.710523). In comparison, the group of companies with more than 20 years of activity $(\mathrm{age}=1)$ show the highest short-term solvency (working capital to total asset, .046256), return (ROI, .0309879; EBITDA_TA, .0011951, ROE, -.0278554), assets (LOGTA: 7.650233), and interest coverage (EBITDA_INT, 1219.338). The analysis of the medians gives a similar picture of the group profiles with some small differences. 
Table 8. Descriptive analysis according to age.

\begin{tabular}{|c|c|c|c|c|c|c|c|c|}
\hline & \multicolumn{4}{|c|}{ Age 0} & \multicolumn{4}{|c|}{ Age 1} \\
\hline Variable & Obs & Mean & Median & Std. Dev. & Obs & Mean & Median & Std. Dev. \\
\hline WC_TA & 2226 & -.1388349 & .0456976 & .9230568 & 1735 & .046256 & .1562643 & .753616 \\
\hline TD_TA & 1958 & .9742124 & .0456976 & .6752313 & 1626 & .7407337 & .6950999 & .5299298 \\
\hline ROI & 1929 & .0309602 & .0315129 & .1675894 & 1621 & .0309879 & .0288525 & .0994749 \\
\hline LOGTA & 2225 & 6.550842 & 6.311999 & 1.747047 & 1735 & 7.650233 & 7.366963 & 1.705909 \\
\hline EBITDA_INT & 2184 & 819.2037 & 1.871885 & 10189.63 & 1723 & 1219.338 & 1.961523 & 10996.46 \\
\hline EBITDA_TA & 2220 & -.0600158 & .0170874 & .3434455 & 1735 & .0011951 & .0249034 & .1937888 \\
\hline CASH_TA & 2208 & .3514962 & .2573193 & .3212774 & 1728 & .2644017 & .1660679 & .2748453 \\
\hline TURNV & 2208 & 1.710523 & 1.241774 & 1.868889 & 1734 & 1.013466 & .746144 & 1.128355 \\
\hline ROE & 2214 & -.0952107 & .0413573 & 4.763281 & 1734 & -.0278554 & .018907 & 2.175353 \\
\hline
\end{tabular}

Age $0=$ if the firm operates in the sector for less than 20 years.

Age 1= if the firm operates in the sector for more than 20 years.

Source: Own elaboration.

The Kruskal-Wallis test (Table 9) shows that the null hypothesis of equality of means in most cases should not be accepted, except for the profitability sector (ROI, ROE, EBITDAFE at 1\%, EBITDA). The test applied to the two age groups shows that they are different for all the variables, except for ROI (at $5 \%$ ).

Table 9. Kruskal-Wallis table.

\begin{tabular}{|l|c|c|c|c|c|c|c|c|c|}
\hline \multicolumn{1}{|c|}{$\begin{array}{l}\text { Variable } \\
\text { (avg) }\end{array}$} & Obs. & Chi-Sq. & P & Obs. & Chi-Sq. & P & Obs & Chi-Sq. & p \\
\hline WC_TA & 3981 & 382.42 & $0.0001^{* *}$ & 3961 & 200.468 & $0.0001^{* *}$ & 3961 & 169.476 & $0.0001^{* *}$ \\
TD_TA & 3584 & 479.254 & $0.0001^{* *}$ & 3584 & 18.885 & $0.0001^{* *}$ & 3584 & 271.686 & $0.0001^{* *}$ \\
ROI & 3550 & 427.679 & $0.0001^{* *}$ & 3550 & 4.232 & 0.1205 & 3550 & 4.303 & $0.0380^{*}$ \\
LOGTA & 3960 & 309.301 & $0.0001^{* *}$ & 3960 & 34.966 & $0.0001^{* *}$ & 3960 & 421.537 & $0.0001^{* *}$ \\
EBITDA_INT & 3907 & 531.335 & $0.0001^{* *}$ & 3907 & 6.897 & $0.0318^{*}$ & 3907 & 7.356 & $0.0067^{* *}$ \\
EBITDA_TA & 3955 & 573.789 & $0.0001^{* *}$ & 3955 & 2.903 & 0.2343 & 3955 & 8.743 & $0.0031^{* *}$ \\
CASH_TA & 3936 & 308.322 & $0.0001^{* *}$ & 3936 & 16.882 & $0.0002^{* *}$ & 3936 & 92.188 & $0.0001^{* *}$ \\
TURNV & 3942 & 12.693 & $0.0004^{* *}$ & 3942 & 72.104 & $0.0001 * *$ & 3942 & 149.687 & $0.0001^{* *}$ \\
ROE & 3948 & 279.410 & $0.0001^{* *}$ & 3948 & 1.173 & 0.5562 & 3948 & 16.329 & $0.0001^{* *}$ \\
\hline
\end{tabular}

*: significant at $5 \%$. **: significant at $1 \%$.

Source: Own elaboration.

The correlation analysis (Table 10) presents high levels for most of the variables in both cases. The number of associations among ratios in the solvent group is larger than for the insolvent group. In 
some cases, we can observe a change in the sign (for instance, in WC_TA with CASH_TA which is positive for the solvent firms and negative for the insolvent ones) and in other cases the significance of a certain correlation (for example, LOGTA and WC_TA appear in the insolvent group, but not in the solvent firms).

Table 10. Correlation analysis according to the state [what state?]

\begin{tabular}{|c|c|c|c|c|c|c|c|c|c|}
\hline \multicolumn{10}{|c|}{ SOLVENT GROUP } \\
\hline Variable & WC_TA & TD_TA & ROI & LOGTA & EBITDA_INT & EBITDA_TA & CASH_TA & TURNV & ROE \\
\hline WC_TA & 1 & & & & & & & & \\
\hline TD_TA & $-0.1814^{*}$ & 1 & & & & & & & \\
\hline $\mathrm{RO} \overline{\mathrm{I}}$ & & $-0.1295^{*}$ & 1 & & & & & & \\
\hline LOGTA & $0.1378^{*}$ & $-0.2702 *$ & $-0.1755^{*}$ & 1 & & & & & \\
\hline EBITDA INT & & $-0.0470 *$ & $0.1253 *$ & & 1 & & & & \\
\hline EBITDA_TA & & $-0.2867^{*}$ & $0.4780^{*}$ & & $0.0919 *$ & 1 & & & \\
\hline CASH_TA & $0.3040^{*}$ & $-0.0636^{*}$ & $0.2211^{*}$ & $-0.4117^{*}$ & $0.1190^{*}$ & & 1 & & \\
\hline TURNV & $-0.0972 *$ & $0.2192 *$ & $0.1724 *$ & $-0.6267^{*}$ & & $0.0702 *$ & $0.3443^{*}$ & 1 & \\
\hline ROE & & $-0.0691 *$ & $0.2029 *$ & $-0.1117^{*}$ & & $0.1473^{*}$ & $0.1196^{*}$ & $0.0589 *$ & 1 \\
\hline \multicolumn{10}{|c|}{ INSOLVENT GROUP } \\
\hline Variable & WC_TA & TD_TA & ROI & LOGTA & EBITDA_INT & EBITDA_TA & CASH_TA & TURNV & ROE \\
\hline WC_TA & 1 & & & & & & & & \\
\hline TD_TA & $-0.3957^{*}$ & 1 & & & & & & & \\
\hline ROI & $0.1555^{*}$ & $-0.2640 *$ & 1 & & & & & & \\
\hline LOGTA & $0.1913^{*}$ & $-0.3195^{*}$ & $0.1485^{*}$ & 1 & & & & & \\
\hline EBITDA_INT & & & 0.0609 & & 1 & & & & \\
\hline EBITDA_TA & $0.4234 *$ & $-0.5545^{*}$ & $0.4272 *$ & $0.2972 *$ & $0.0612 *$ & 1 & & & \\
\hline CASH_TA & $-0.0968^{*}$ & $0.0849 *$ & & $-0.4104^{*}$ & & $-0.2048^{*}$ & 1 & & \\
\hline TURNV & $-0.2181 *$ & $0.3182 *$ & & $-0.5685^{*}$ & & $-0.3505 *$ & $0.3580 *$ & 1 & \\
\hline ROE & & $-0.1076^{*}$ & $0.0913 *$ & & & $0.1650 *$ & & & 1 \\
\hline
\end{tabular}

*: significant at 5\%. **: significant at $1 \%$.

Source: Own elaboration.

To summarize, the ratios that determine insolvency are the same when we compare the three criteria. Nevertheless, it is also true that each characteristic (number of insolvencies and age) provides fewer ratios and is not coincident with the other groups. In general, short-term solvency, return, size, indebtedness and turnover are the common features in each of the comparisons. Lastly, it is remarkable that profitability is the only factor that is the same throughout.

\section{Application of survival analysis.}

The time to the event was computed in months and days and we assume that the firms that appear in the database as "active" have not filed for bankruptcy. The Kaplan-Meier survival curve has been graphed by state, sector and age.

As can be seen in Figure 1, the insolvent firms exhibit a drop in the survival curve from year five while the solvent group presents a constant curve. Therefore, the probability of surviving decreases abruptly after 5 years of activity or, alternatively, most firms fail after year 5 . 
Figure 1. Kaplan Meier survival curves by state.

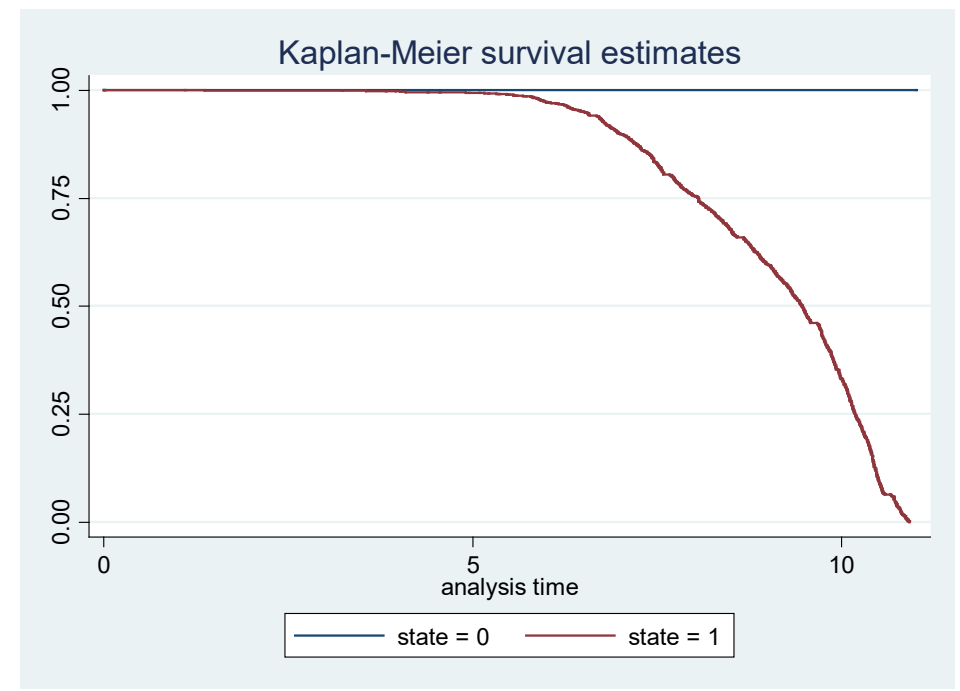

State $=0$ solvent firms

State $=1$ insolvent firms.

Source: Own elaboration.

When we compare the survival curves grouping by the vulnerability of industries to insolvency (Figure 2), we find that the three curves do not show any significant differences in survival probability among the three groups. It means that the number of insolvencies has no effect on the survival probabilities of the firm or, in other words, the number of insolvencies in that industry does not affect a firm's survival.

Figure 2. Kaplan-Meier survival curves by groups.

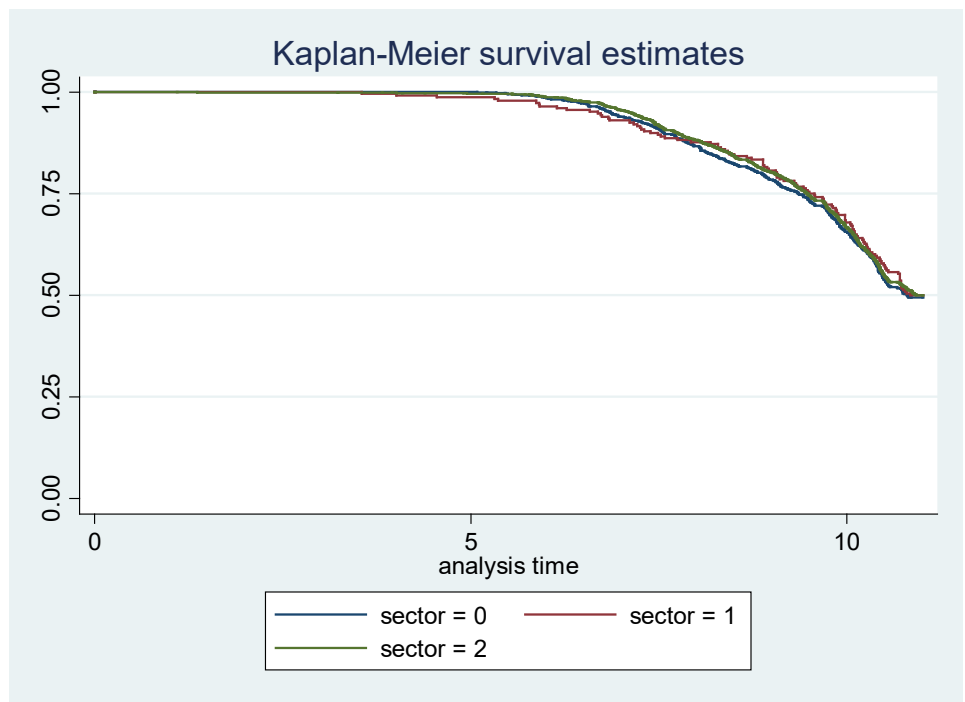

Sector $=0$ : if the firm belongs to the sectors with the highest percentage of bankruptcies. Sector $=1$ : if the firm belongs to the sector with the lowest percentage of bankruptcies. Sector $=2$ : if the firm belongs to other sectors.

Source: Own elaboration. 
Age (Figure 3) is the second grouping categorical variable and shows a difference between the two groups, even though it is not as clear at the end (past year 10). It seems that more mature firms show less probability of surviving than younger firms, but only as times advances.

Figure 3. Kaplan-Meier survival curves by groups.

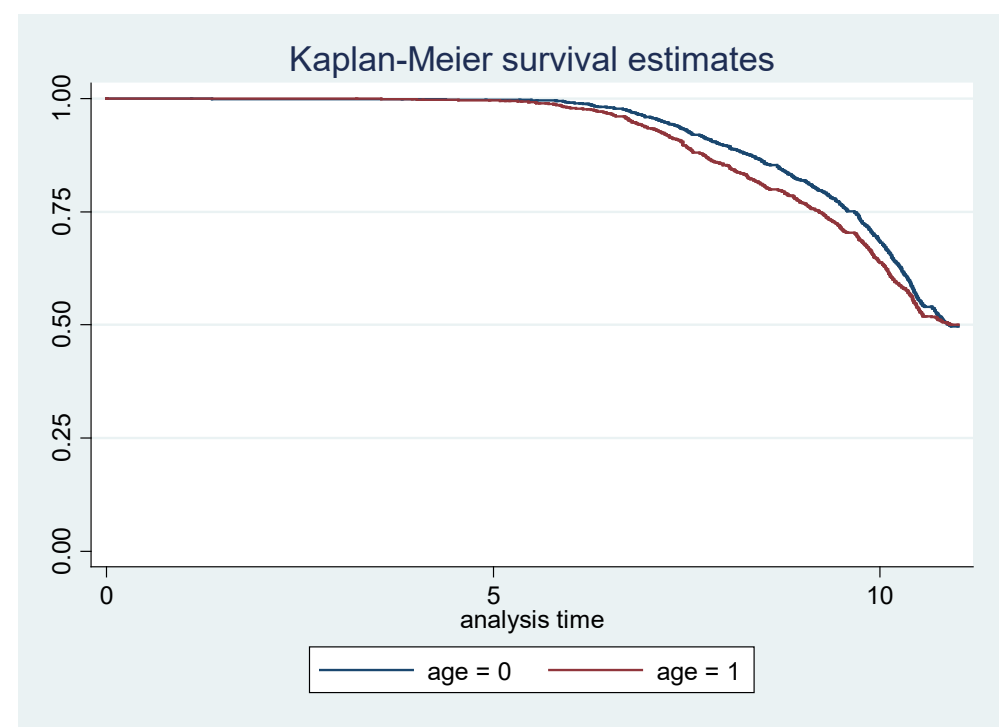

Age $0=$ if the firm operates in the sector for less than 20 years.

Age $1=$ if the firm operates in the sector for more than 20 years.

Source: Own elaboration.

\subsection{Estimation using models.}

In the previous section, the Kaplan-Meier survival estimates allow us to conclude that no difference in survival probability exists according to sectors, although it is affected by age.

In this section, we take a deeper look at the variables that explain these results: firstly, by taking the whole sample; secondly, by the propensity to insolvency of each group; and, finally, by age. In order to do this, we have applied the Cox PH model.

The starting point is the complete set of ratios for selecting the potential candidate for the final model $(p=0.05)$, applying the Chi-Square test for each variable. Once we had the potential covariates, we applied the test of proportionality with the significant ratios. Given that this assumption is essential for the model, the significant ratios that did not meet this requirement were incorporated as timedependent covariates. The final step consisted of testing the possible interactions in order to improve the models.

Sectors with the highest number of insolvencies (group 0):

Table 11 shows the significant covariates (at 1\%) and the interactions between variables that are significant for the hazard model.

Models 1 to 6 refer to the industries with the highest number of bankruptcies; models 7 to 12 are based on the industries with the lowest number of bankruptcies; and, finally, models 13-16 are for the reference group. 
Table 11. Survival models with and without interactions for each group of sectors.

\begin{tabular}{|c|c|c|c|c|c|c|c|c|c|c|c|c|c|c|c|}
\hline & (1) & (2) & (3) & (4) & (5) & (6) & (7) & (8) & (9) & (10) & (11) & (12) & (13) & (14) & (15) \\
\hline $\begin{array}{l}\text { ROI } \\
\text { CASH_TA } \\
\text { ROE } \\
\text { TURNV } \\
\text { LOGTA } \\
\text { EBITDA_INT } \\
\text { WC_TA } \\
\text { TD_TA } \\
\text { agex } R O I \\
1 \\
\text { agex } x \text { LOGTA } \\
0 \\
1 \\
\text { Agex } \\
\text { EBITDA_INT } \\
0 \\
1 \\
\text { Agex } \\
\text { EBITDA_TA } \\
0 \\
1\end{array}$ & $\begin{array}{r}0.2259 * * \\
0.084491 * * \\
0.97431 * \\
0.7538 * *\end{array}$ & $0.9633^{* *}$ & $\begin{array}{r}0.3418^{*} \\
0.0941^{* *} \\
0.9764^{*} \\
0.7633^{* *} \\
\\
\\
0.0211^{* *} \\
1.5869^{* *} \\
1.6652^{* *}\end{array}$ & $0.9120^{* *}$ & $\begin{array}{r}-1.0744^{* *} \\
-2.3625^{* *} \\
-0.0238^{*} \\
-0.2700^{* *} \\
\\
-3.8579^{* *} \\
0.4618^{* *} \\
0.5099^{* *}\end{array}$ & $-0.0920 * *$ & $\begin{array}{c}0.0973 * * \\
0.9999 *\end{array}$ & $0.9258 * *$ & $\begin{array}{r}2.8172 * * \\
2.9936^{* *} \\
\\
0.9999^{*} \\
0.9999^{* *} \\
\\
1.001 \\
0.0024 * *\end{array}$ & $0.8256^{* *}$ & $\begin{array}{r}1.0357^{* *} \\
1.0964^{* *} \\
-0.000156^{*} \\
-0.000128^{* *} \\
\\
0.0001 \\
-6.0066^{* *}\end{array}$ & $-1.9158 * *$ & $\begin{array}{l}0.1709^{* *} \\
0.1149 * * \\
\\
0.8963 * * \\
1.1290^{* *}\end{array}$ & $\begin{array}{l}0.9641 * * \\
0.9518^{* *}\end{array}$ & $\begin{array}{r}-1.766^{* *} \\
-2.1636^{* *} \\
\\
-0.03652^{* *} \\
-0.0493^{* *} \\
-0.1093^{* *} \\
0.1213^{* *}\end{array}$ \\
\hline $\begin{array}{l}\text { Likelihood } \\
\text { Ratio } \\
\text { (LR) Chi- } \\
\text { Square } \\
\end{array}$ & & $313.02 * *$ & & $346.73 * *$ & & $346.73 * *$ & & $114.47 * *$ & & $128.14^{* *}$ & & $128.14 * *$ & & $714.17 * *$ & $714.17 * *$ \\
\hline $\begin{array}{l}\text { Number of } \\
\text { Observations }\end{array}$ & & 1041 & & 1041 & & 1041 & & 226 & & 226 & & 226 & & 2096 & 2096 \\
\hline
\end{tabular}

$*$ : significant at $5 \%$. $* *$ : significant at $1 \%$.

Group 0: the sectors with the highest insolvency incidence.

(1) Model without interactions (hazard ratios): invariant covariates

(2) Model without interactions (hazard ratios): time dependent covariates

(3) Model with interactions (hazard ratios): invariant covariates

(4) Model with interactions (hazard ratios): time dependent covariates.

(5) Models with interactions and coefficients.

(6) Models with interactions and coefficients: time dependent covariates. 
Group 1: the sectors with the lowest insolvency incidence.

(7) Model without interactions (hazard ratios): invariant covariates.

(8) Model without interactions (hazard ratios): time-dependent covariates.

(9) Model with interactions (hazard ratios): invariant covariates.

(10) Model with interactions (hazard ratios): time-dependent covariates.

(11) Model with interactions and coefficients.

(12) Model with interactions and coefficients: time-dependent covariates.

Group 2: reference group.

(13) Model without interactions: invariant covariates.

(14) Model without interactions: time-dependent covariates.

(15) Model with interactions and coefficients.

(16) Model with interactions and coefficients: time-dependent covariates. Source: Own elaboration. 
Regarding the first group (column 1), all the ratios have a negative effect on the time of insolvency, especially cash to total asset (0.084491) and ROI (0.2259), which show the strongest impact on the hazard functions while asset turnover (0.7538) and ROE (0.97431) have only a slight effect. Therefore, liquidity and asset return are the two significant covariates for determining the time to survive (column 2). LOGTA has been selected and included in the model as a time-dependent variable. In order to make this interpretation, the variable has been divided into two discrete groups: below and above the median. For group 0 (below the median) the curve is above group 1 (above the median) until year 7-8. Subsequently, the first group presents a decline of the survival curve (Figure 4).

Figure 4. Kaplan-Meier survival curves for LOGTA.

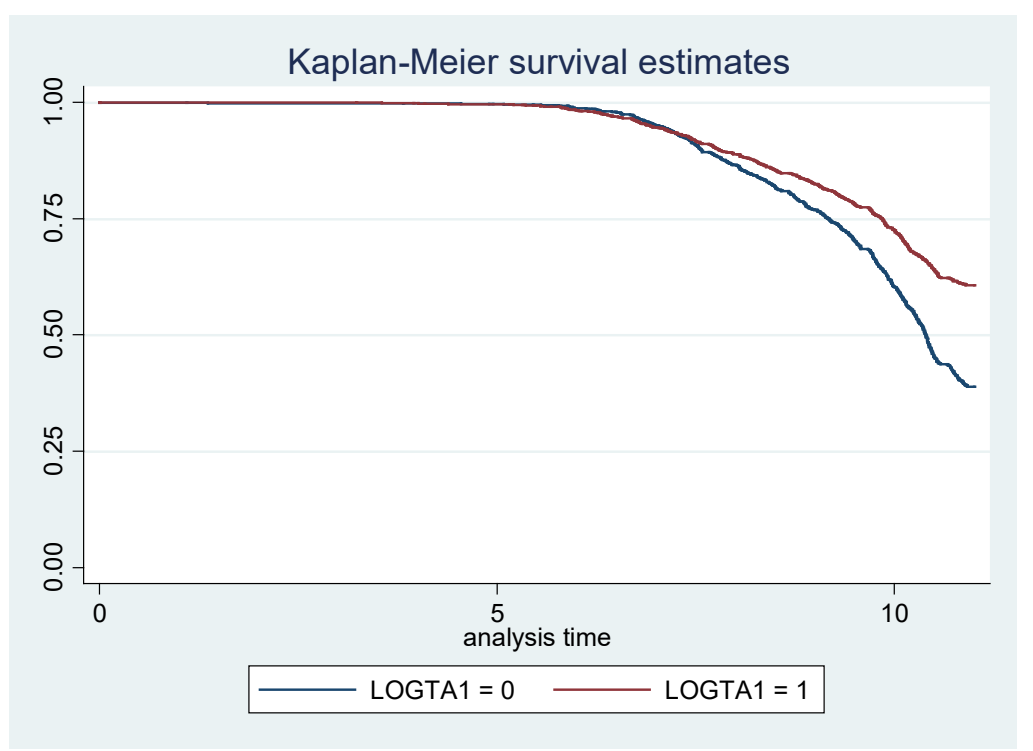

LOGTA $1=0$ if the firm is below the median

LOGTA $1=1$ if the fim is above the median.

Source: Own elaboration.

The model (columns 3 and 4) with interactions includes some significant relationships. The years of activity (age) and ROI allow us to conclude that in the firms that are less than 20 years old the effect of an increase of profitability is less than for the firms in the second group (age $0 \times$ ROI : exp (-1.0744) $=0.3415$ (decrease by 64\%); age $1 \times$ ROI: $\exp (-1.0744-3.8579)=0.007$ (decrease by $99 \%) ;$ age $0 x$ LOGTA : $\exp (0.4618)=1.5869$ (increase by 58\%); age $1 \times$ LOGTA: $\exp (0.5099523)=1.6651$ (increase by $66 \%)$ ). Therefore, an increase in profitability is more important for older firms than for younger firms. The second interaction age x LOGTA shows the effect of an increase in size depending on age. This result is inconsistent as in each case it is greater than one and means that an increase in size also boosts insolvency. Given that LOGTA is a time dependent covariate, it implies that the interaction with this variable does not fulfil the proportionality assumption.

The last columns (5 and 6) present the model with interactions and, instead of the hazard ratio for each variable, the coefficient for each variable appears.

Sectors with the lowest number of insolvencies (group 1):

The hazard models here are different from the previous one (columns 7 to 12). If we look at the model without interactions (7-8), the only variables in common with group 0 are CASH_TA and LOGTA. Therefore, it means that liquidity and size are the characteristics that determine the survival time. Neither profitability nor indebtedness play a role in this group. The second observation is the 
effect on the time of insolvency and here, surprisingly, only cash is really important as a one unit increase in cash decreases the rate of insolvency versus solvency by $99 \%$ (hazard rate: 0.0973 ). The ratio EBITDA_INT has a marginal effect, only a reduction of $1 \%$ of the rate of insolvency versus solvency (hazard rate: 0.9999 ). The role of size is similar to the previous group.

The next question is the inclusion of interactions (9 to 12). Here, again, some unexpected results emerge. The single ratios cease to be significant (except LOGTA) and the interactions with age are the only covariates, in particular, age x LOGTA (not consistent, as it was mentioned earlier), age $\mathrm{x}$ EBITDA_INT and age $\mathrm{x}$ EBITDA_TA. This interpretation (age0 $x$ LOGTA increases the rate of insolvency by $181 \%$; age $1 \times$ LOGTA increases the rate of insolvency by $199 \%$; age $0 \times$ EBITDA_INT decreases the rate of insolvency by $1 \%$; agel $x$ EBITDA_INT decreases the rate of insolvency by $1 \%$; age $\times$ EBITDA_TA increases the rate of insolvency by $1 \%$; agel $x$ EBITDA_TA decreases the rate of insolvency by $99 \%$ ) is misleading for age $\mathrm{x}$ LOGTA, which is the only interaction with a meaningful effect. The interaction of age $x$ EBITDA INT is not significant and age $x$ EBITDA TA has a significant effect only for group 1 . Therefore, we can conclude that in this case, although the model is significant, the meanings of the interactions are confusing.

\section{Reference sectors (group 2):}

This includes firms that do not belong to the other sectors in order to make comparisons. Given that this is the most heterogeneous, the results per se could be less meaningful than the others (columns 13-16).

This group is more similar to the one of the highest percentage of insolvencies) than the other. Effectively, ROI (0.1709), CASH_TA (0.1149), LOG_TA (0.9518) and TUNV (0.9641) are significant in both groups 0 and 2. Nevertheless, ROE appears in the first group, but not here, and WC_TA and TD_TA appear here, but not in the 0 group. The similarities with group 1 are very small as the only variables that appear in both models are CASH_TA and LOGTA.

The interpretation of the signs allows us to say that an increase of one unit in WC TA $(0.8963)$ reduces the hazard of being insolvent by $11 \%$; ROI is more effective $(0.1709)$, with a reduction of $83 \%$, and the same happens with CASH_TA (0.1149), with a reduction of $89 \%$. Although the same interactions with age were applied in this sector, none of them was significant.

The group most affected by insolvency and the reference group shows some common factors, such as return and turnover. The group least affected by bankruptcy is the most dissimilar as the only significant variables are based on EBITDA.

The main results allow us to confirm that both liquidity and size are the main factors in determining survival time in any of the analyzed groups. Profitability and turnover are important for determining the survival of a firm in the reference group and the one with the highest number of insolvencies. This is not the case for the second group. This one is the most dissimilar, not only because of the explanatory variables, but also due to the interaction signs. We can therefore conclude that the characteristics of this group are distinct from the others.

\section{Logit results.}

We applied logit analysis with the objective of estimating the probability of insolvency for each group. The results are shown in Table 12.

The comparison of the models with and without interactions reveals some interesting insights. The group with the highest numbers of insolvencies shows that an increase by one unit in return (ROI, 0.0059326), liquidity (CASH_TA, 0.0351236), turnover (TURNV, 0.7779144), and size (LOGTA, 
0.5797339) decreases the odds of insolvency (vs. solvency), but an increase in one unit by short-term solvency (WC TA, 1.926575) and age (1.5935) increases the same probability. The model with interactions shows that age is an important variable in this group; it appears as a single variable and in conjunction with indebtedness (TD_TA 1.41638 for value 0 and 4.029322 for value 1 ) and return (ROI, $0.0002531)$.

Table 12. Logit models for each group.

\begin{tabular}{|c|c|c|c|c|c|c|}
\hline \multirow[b]{2}{*}{ Odd ratios } & \multicolumn{2}{|c|}{ Group 0} & \multicolumn{2}{|c|}{ Group 1} & \multicolumn{2}{|c|}{ Group 2} \\
\hline & $\begin{array}{l}\text { Model without } \\
\text { interactions }\end{array}$ & $\begin{array}{l}\text { Model with } \\
\text { Interactions }\end{array}$ & $\begin{array}{l}\text { Model without } \\
\text { interactions }\end{array}$ & $\begin{array}{l}\text { Model with } \\
\text { interactions }\end{array}$ & $\begin{array}{l}\text { Model without } \\
\text { interactions }\end{array}$ & $\begin{array}{l}\text { Model with } \\
\text { interactions }\end{array}$ \\
\hline & & & & & & \\
\hline$W C \_T A$ & $1.926575^{* *}$ & & $.0990294 *$ & & $.6513558 * *$ & $.4933654 * *$ \\
\hline$T D_{-} T A$ & & & $16.57591 * *$ & & $2.580793 * *$ & $2.586244 * *$ \\
\hline$R O \bar{I}$ & $.0059326^{* *}$ & $.0291733 * *$ & & & $.0366056^{* *}$ & $.0675444 * *$ \\
\hline CASH_TA & $.0351236^{* *}$ & $.0510667 * *$ & & & $.0587385^{* *}$ & $.0612975 * *$ \\
\hline$R O E$ & & & & & $.9553534 * *$ & $.9550634 * *$ \\
\hline$T U R N V$ & $.6679144 * *$ & $.6616689^{* *}$ & & $.373514 * *$ & & $.4679028^{* *}$ \\
\hline$L O G T A$ & $.5797339 * *$ & $.5733134 * *$ & $.2315606^{* *}$ & $.2288935^{* *}$ & $.4231289 * *$ & $.4212577 * *$ \\
\hline$E B I T D A \_F E$ & & & .9998674 & & & \\
\hline EBITDA_TA & & & 373.3959 & & & \\
\hline Age (1) & $1.5935^{* *}$ & & 2.943365 & & $1.839153^{* *}$ & $1.972945 * *$ \\
\hline $\begin{array}{r}\text { Interactions } \\
\text { age } \times \text { TD TA }\end{array}$ & & & & & & \\
\hline & & $1.41638^{*}$ & & & & \\
\hline & & $4.029322 * *$ & & & & \\
\hline age $x$ ROI & & & & & & \\
\hline 1 & & $.0002531 * *$ & & & & $.0990508 *$ \\
\hline 0 & & & & .5014957 & & \\
\hline & & & & $.0003673 * *$ & & $1.559086^{*}$ \\
\hline age $x$ LOGTA & & & & & & \\
\hline 1 & & & & 1.2407 & & \\
\hline Constant & $112.0871 * *$ & 137.3461 & $15608.28^{* *}$ & $98656.82 * *$ & $848.8225^{* *}$ & $859.8955^{* *}$ \\
\hline Pseudo $\mathrm{R}^{2}$ & $0.2273^{* *}$ & $0.2453 * *$ & $0.4716^{* *}$ & $0.4445 * *$ & $0.2841 * *$ & $0.2872 * *$ \\
\hline $\begin{array}{r}\text { Number of } \\
\text { observations }\end{array}$ & 945 & 945 & 225 & 225 & 2096 & 2096 \\
\hline
\end{tabular}

*: significant at 5\%. **: significant at $1 \%$.

Source: Own elaboration.

The firms that belong to the sectors with the lowest number of insolvencies show that short-term solvency (WC_TA, 0.0990294) and size (LOGTA, 0.2315606) show a fall in the relative probability of insolvency versus solvency. Nevertheless, indebtedness (TD_TA, 16.57591) has the opposite effect. The inclusion of the interactions almost makes the previous single ratios disappear and the only relevant factors with a negative effect on the odds of insolvency are turnover (TURNV, 0.373514) and size (LOGTA, 0.2288935). The significant interactions are age $\mathrm{x}$ WC_TA, which decreases the odds by 0.5014957 in the value 0 and 0.0003673 in the value 1 , so the effect is stronger for the first age group. The second interaction is not significant.

The reference group (2) shows a similar pattern to the first group. Regarding the first model without interactions, the variables with a negative effect of insolvency are short-term solvency (WC_TA, .6513558), return (ROI, 0.0366056 and ROE, 0.955534), liquidity (CASH_TA, .0587385), and size (LOGTA, 0.4231289). The variables with the opposite effect are indebtedness (TD_TA, 2.580793) and age (1.839153). The model with interactions is very similar, except for turnover, which 
now appears with a negative effect (TURNV, 0.4679028), and the significant interactions are age $\mathrm{x}$ ROI $(0.0990508$ at 5\%) and age $x$ WC_TA (only significant for Group $1(1.559086$ at 5\%).

The group with the highest numbers of insolvency and the reference group are very similar with respect to the explanatory variables and the fit of the model. The most dissimilar is group 1 (with the lowest number of insolvencies) not only because of the number of single ratios and the composition, but also because of the fit of the model. Therefore, we can conclude that this group responds to different factors in order to explain the time and the probability of bankruptcy.

The comparison of survival models with logit models allows us to detect some differences, bearing in mind that each technique pursues different objectives.

Group with the highest number of insolvencies: if we look at the different selected variables in the models, the survival model without interactions selects ROE as significant (negative effect), but in the logit it does not appear and instead, WC_TA (positive) and age (positive) appear. The addition of interactions produces more differences. For instance, the survival model includes age x LOGTA (inconsistent), but it is not present in the logit model. The logit, nevertheless, selects as a meaningful variable age $\mathrm{x}$ TD_TA that the survival model does not select. Therefore, we can conclude that ROE is significant when we want to estimate the survival time of the firm in this group, but when we need to study the odds of insolvency WC_TA appears instead. The interactions clearly show that age is significant and it can be said that the effect is less positive in the group of older firms than in the younger group.

Group with the lowest number of insolvencies: the unique ratio that appears in both techniques is LOGTA. CASH_TA is only relevant for the survival model and WC_TA and TD_TA only appears in the logit. When the interactions are included in this group the only common variable is LOGTA, TURNV is shown in the logit and the interactions with age are different, except for age $\mathrm{x}$ LOGTA which is not significant in the logit (in the survival model age $x$ EBITDA_INT and age $x$ EBITDATA, in the logit age $\mathrm{x}$ WC_TA). Here, we can state that while liquidity (CA-SH_TA), interest coverage (EBITDA_INT) and size (LOG_TA) are the only relevant factors in order to determine the time of survival, the odds of insolvency versus solvency are moulded by short-term solvency, indebtedness, and size.

Reference group: the differences in the model without interactions come from ROE and AGE that appear in logit, but not in the survival model. It is worth mentioning that ROE has a negative effect on the odds, but age shows a positive sign. The survival model only selects variables, not interactions. From these results, we can state that the factors that determine the survival time and the odds of insolvency are more similar here than in the other groups. Short-term solvency (WC_TA), asset return (ROI), liquidity (CASH_TA), and size (LOGTA) are the common factors in both techniques. Age only appears in the logit model with a positive sign, so implying that the change from the younger to the older group increases the odds of insolvency.

To summarize, if liquidity and size are the factors that determine the time to insolvency, the occurrence of bankruptcy is explained by short-term solvency, size, and turnover. This means that the event depends on more variables than the time to the event (Table 13). 
Table 13. Main findings of hazard models and logit models.

\begin{tabular}{|c|c|c|}
\hline GROUP & HAZARD MODELS & LOGIT MODELS \\
\hline The highest insolvency & $\begin{array}{l}\text { - Cash and profitability show negative } \\
\text { effects on insolvency } \\
\text { - No selected ratio presents a positive sign. } \\
\text { - The interaction of age and profitability } \\
\text { shows that it is more powerful for the } \\
\text { older than the younger firms. }\end{array}$ & $\begin{array}{l}\text { - Return, liquidity, turnover and } \\
\text { size decrease insolvency odds. } \\
\text { - Short-term solvency and age } \\
\text { increase insolvency } \\
\text { probability. }\end{array}$ \\
\hline The lowest insolvency & $\begin{array}{l}\text { - Liquidity and size are the determinants of } \\
\text { survival. } \\
\text { - Neither profitability nor indebtedness } \\
\text { play a role. } \\
\text { - Misleading interactions }\end{array}$ & $\begin{array}{l}\text { - Short-term solvency and size } \\
\text { decrease probability of } \\
\text { insolvency. } \\
\text { - Indebtedness has the opposite } \\
\text { effect. }\end{array}$ \\
\hline The reference group & $\begin{array}{l}\text { - Profitability, cash, size and turnover are } \\
\text { significant. }\end{array}$ & $\begin{array}{l}\text { - Short-term solvency, return, } \\
\text { liquidity and size have a } \\
\text { negative effect on insolvency. } \\
\text { - Indebtedness and age have the } \\
\text { opposite effects. }\end{array}$ \\
\hline
\end{tabular}

Source: Own elaboration.

\section{Discussion.}

The most remarkable results to emerge from the data are that the survival for insolvent firms drops from the five year mark onwards; the propensity to insolvency in the industry does not play a role; and the years of activity seem to be important as the more years there are, the lower is the probability of survival. Regarding the variables to explain survival, liquidity and size appear for all the industries, but profitability and turnover are also important for the sectors with the highest level of bankruptcies.

The probability of insolvency estimated by logit shows differences among groups and the variables that explain it are more similar when the groups have a large number of insolvencies. In general, the variables coincide with the previous ones.

As far as we know, this is the first time that a study analyses the influence of industry vulnerability to default directly in the sample and applies two different techniques. The results widen our knowledge of the effect of industry on survival and the probability of insolvency.

The results confirm some of those found in the previous literature. For example, the lack of differences among groups in the survival models is in line with Kenedy (2000). However, it does not support the importance of including industry effects in hazard models (Chava \& Jarrow, 2014; Lang \& Stulz, 1992). The effect of age is difficult to compare, as it has been included as a categorical variable here. Nevertheless, it is in agreement with Berkovitch and Israel (1998), who also found that failure is higher for mature firms.

With respect to the relevance of liquidity, size, profitability and turnover as significant in the survival and the logit, previous literature supports these findings: for instance, profitability (Chava \& 
Jarrow, 2004, among others) and size (Huang \& Lee, 2013, James \& Kazalislan, 2014, among others), although our study differs from most of the previous research as this last variable has been computed using turnover, but not assets.

It is worthwhile noting that liquidity confirms the finding of James and Kazalislan (2014) about the use of more cash in industry with significant risk exposure. In our case, the relevance of cash to total asset can be seen in the group of the highest level of insolvencies.

It is plausible that a number of limitations may could have influenced the results obtained. Firstly, in the sample selection as we used only SME entities; secondly, the period analyzed (2012-2016), in which the Spanish economy moved from depression to a certain stabilization; and finally, the variables. The use of the percentage of insolvencies over the population to define the vulnerability of an industry could be a reasonable measure, but other measures should be considered, especially the concentration index (Chiu, Pena \& Wang, 2013; Zhang, Altman \& Yen, 2010).

Further work needs to be done to analyze in greater depth the fact that survival of the firm is not affected by the vulnerability of the industry and the fact that the years of activity have a negative effect on survival.

\section{Conclusions.}

The usefulness of comparing sectors with the highest and lowest number of insolvencies is that it highlights the similarities and differences both in the process to bankruptcy and in the occurrence of the event. Besides, the analysis has been extended to see if the years of activity plays a role in insolvency.

The main conclusion is that sector does not seem significant in determining the length of time to bankruptcy (or survival), but it seems to be more important in the probability of the event. However, the analysis of the causes that lead to the insolvency allow us to conclude that some of them are common to all the groups (liquidity and size have a positive effect on time of survival), but others are particular for each group (especially for the one with the lowest number of insolvencies). When we compare it with a reference group made up of a large variety of sectors, the group that exhibits the higher number of bankruptcies is similar and the variables that determine insolvency are common among them.

The probability of insolvency is determined by some variables that also appear in the survival models and, in this case, the ratios show more similarities among groups than in the previous models. The occurrence of the event is mainly explained by turnover and short-term solvency. Size and turnover have negative effects on bankruptcy. Age is also a common factor, but with a positive effect.

\section{References}

Aertz, K., \& Pope, P.F. (2013). Common factors in default risk across countries and industries. European Financial Management, 19(1), 108-152.

Altman, E.I. (1968). Financial ratios, discriminant analysis and the prediction of corporate bankruptcy. The Journal of Finance, 13(4), 589-609.

Anchor, J. (2017). The impacts of risk-taking behaviour and competition on technical efficiency: evidence form the Chinese banking industry. Research in International Business and Finance, 41, 90-104.

Arellano, A.S., Gil, J.A., \& Martínez, A.H. (2003). El análisis discriminante en la previsión de la insolvencia en las empresas de seguros de no vida. Spanish Journal of Finance and Accounting/Revista Española de Financiación y Contabilidad, 32(116), 183-233. 
Beaver, W.H. (1966). Financial ratios as predictors of failure. Empirical Research in Accounting: Selected Studies Journal of Accounting Research, 5(supplement), 71-111.

Berkovitch, E., \& Israel, R. (1998). The bankruptcy decision and debt contract renegotiations. European Finance Review, 2(1), 1-27.

Bernal-Delgado, E., Campillo-Artero, C., \& García-Armesto, S. (2014). Oferta sanitaria y crisis: financiamos los bienes y servicios según su valor o caemos en la insolvencia. Informe SESPAS 2014. Gaceta Sanitaria, 28, 69-74.

Bhimani, A., Gulamhussen, M.A., \& Lopes, S.R. (2010). Accounting and non-accounting determinants of default: An analysis of privately-held firms. Journal of Accounting and Public Policy, 29(6), 517532.

Bhimani, A., Gulamhussen, M.A., \& Lopes S.R. (2013). The Role of Financial, Macroeconomic, and Non-financial Information in Bank Loan Default Timing Prediction. European Accounting Review, 22(4), 739-763. https://doi.org/10.1080/09638180.2013.770967

Blossfeld, H.P., \& Rohwer, G. (1995). Techniques of event history modelling. New York: Laurence Edbaum Associates.

Brown, C.O., \& Dinç, I.S. (2011). Too many to fail? Evidence of regulatory forbearance when the banking sector is weak. Review of Financial Studies, 24(4), 1378-1405. https://doi.org/10.1093/rfs/hhp039.

Brozyna, J., Mentel, G., \& Pisula, T. (2016). Statistical methods of the bankruptcy prediction in the logistics sector in Poland and Slovakia. Transformations in Business \& Economics, 15(1), 80-96.

Bunn, P., \& Redwood, V. (2003). Company Accounts-Based Modelling of Business Failures and the Implications for Financial Stability (December 2003). Bank of England Working Paper No. 210. https://ssrn.com/abstract=598276 or http://dx.doi.org/10.2139/ssrn.598276

Chava, S., \& Jarrow, R. (2004). Bankruptcy Prediction with Industry Effects. Review of Finance, 8(4), 537-569. https://doi.org/10.1093/rof/8.4.537

Chiu, W., Pena, J.I., \& Wang, C. (2013). "Do structural constraints of the industry matter for corporate failure prediction? Investment Analysts Journal, 42(78), 65-81. https://doi.org/10.1080/10293523.2013.11082562

De Llano, P., Piñeiro, C., \& Rodríguez, M. (2016), "Predicción del fracaso empresarial: Una contribución a la síntesis de una teoría mediante el análisis comparativo de distintas técnicas de predicción”, Estudios de economía, 43(2), 163-198.

Edminster, R.O. (1972). An empirical test of financial ratio analysis for small business failure prediction. Journal of Financial and Quantitative Analysis, 7(2), 1477-1493.

Gabas, F. (1990). Técnicas actuales de análisis contable. Evaluación de la Solvencia Empresarial. España. Ministerio de Economía y Hacienda.

Gallego, A., Gómez, C., \& Yañez, L. (1997). Modelos de predicción de quiebras en empresas no financieras. Actualidad Financiera, 5, 3-14.

García, D., Calvo, A., \& Arques, A. (1997). Factores discriminantes del riesgo financiero en la industria manufacturera española. Predicción de la insolvencia empresarial. Asociación Española de Contabilidad y Administración de Empresas, AECA, Madrid. 
Geopalan, R., \& Xie, K.Z. (2011). Conglomerates and Industry distress. Review of Financial Studies, 24(11), 3642-3687.

Hsu, P.H. (2011). Innovate to survive: the effect of technology competition on corporate bankruptcy. Financial Management, 40(4), 1087-1117.

Huang, H.H., \& Lee, H.H. (2013). Product market competition and credit risk. Journal of Banking and Finance, 37(2), 324-340. https://doi.org/10.1016/j.jbankfin.2012.09.001.

Huang, C.M. (2015). A note on board characteristics, ownership structure and default risk in Taiwan. Accounting and Finance, 55(1), 57-74.

Iannota, G., Nocera, G., \& Sironi, A. (2007). Ownership structure, risk and performance in the European banking. Journal of Banking and Finance, 31(7), 2127-2149.

Irvine, P.J., Park, S.S., \& Yıldızhan, Ç. (2015). Customer-base concentration, profitability, and the relationship life cycle. The Accounting Review, 91(3), 883-906.

Iturrioz, J., \& Martín, S. (2013). El tamaño como elemento determinante de la insolvencia en las sociedades cooperativas: estudio a partir de los procesos concursales. REVESCO Revista de Estudios Cooperativos, 111, 90-107.

James, C., \& Kizilaslan, A. (2014). Asset Specificity, Industry-Driven Recovery Risk, and Loan Pricing. Journal of Financial and Quantitative Analysis, 49(3), 599-631.

Kanatas, G., \& Qui, J.P. (2004). Imperfect competition, debt, and exit. Financial Management, 13(2), 2949.

Kaplan S.N., \& Milton, B.A. (2012). How has CEO turnover changed? International Review of Finance, $12(1), 57-87$.

Karan, M.B., Arslan, O, \& Alatli, M. (2009). Detection of factors leading to business failure for petroleum filling. Ikitsat Isletme Ve Finans, 24(282), 9-26.

Kennedy, R.E. (2000). The effect of bankruptcy filings on rivals' operating performance: Evidence form 51 Large Bankruptcies. International Journal of the Economics and Business, 7(1), 5-25.

Kim, Y., Anderson, D.R., Amburgey, T.L., \& Hickman, J.C. (1995). The use of Event History Analysis to examine insurer insolvencies. The Journal of Risk and Insurance, 62(1), 94-110.

Kleinbaum, D.G., \& Mitchel K. (2010). Survival analysis. Vol. 3. New York: Springer.

Laffarga, J., Martín, J.L., \& Vázquez, M.J. (1985). El análisis de la solvencia en las instituciones bancarias: propuesta de una metodología y aplicaciones a la banca española. ESIC-Market, 48, 51-73.

Laffarga, J., Martín, J.L., \& Vázquez, M.J. (1986). El pronóstico a largo plazo del fracaso en las instituciones bancarias: metodología y aplicaciones en el caso español. ESIC-Market, 54, 113-167.

Laffarga, J., Martín, J.L, \& Vázquez, M.J. (1991). La predicción de quiebra bancaria: el caso español. Revista Española de Financiación y Contabilidad, 20(66), 151-163.

Laguillo, G. (2016). Predicción de insolvencia en los sectores económicos: un análisis comparativo [Dissertation thesis]. Universidad de Málaga. 
Laitinen, E.K. (2005). Survival Analysis and Financial Distress Prediction: Finnish Evidence. Review of Accounting and Finance, 4(4), 76-90. https://doi.org/10.1108/eb043438

Lane, W.R., Looney, S.W., \& Wansley, J.W. (1986). An application of the cox proportional hazards model to bank failure. Journal of Banking and Finance, 10(4), 511-531.

Lang, L., \& Stultz, R. (1992). Contagion and competitive intra-industry effects of bankruptcy announcements: An empirical analysis. Journal of Financial Economics, 32, 45-60.

LeClere, M.J. (2000). The Occurrence and Timing of Events: Survival Analysis Applied to the Study of Financial Distress. Journal of Accounting Literature, 19, 158-189.

LeClere, M. (2005) Time-Dependent and Time-Invariant Covariates Within a Proportional Hazards Model: A Financial Distress Application. Review of Accounting and Finance, 4(4), 91-109, https://doi.org/10.1108/eb043439

Lizarraga, F. (1997). Los flujos de tesorería en la predicción del fracaso empresarial. Actualidad Financiera, 2(4), 73-93.

Lizarraga, F., \& Archel, P. (1998). Utility of accounting information on the process of failure: analysis of the medium sized Spanish manufacturing sector. $21^{\text {st }}$ Congress of the European Accounting Association. Ambers: European Accounting Association.

López-Gutiérrez, C., Torre-Olmo, B., \& Sanfilippo-Azofra, S. (2011). ¿Puede una ley concursal ser eficiente? Una aproximación conceptual a la solución de los problemas de insolvencia. Innovar, 21(41), 125-144.

López-Herrera, D., Moreno, J., \& Rodríguez, P. (1994). "Modelos de previsión del fracaso empresarial: aplicación a entidades de seguros en España". Esic-Market, 84, 83-125.

Lukason, O., Laitinen, E.K., \& Suvas, A. (2016). Failure processes of young manufacturing micro firms in Europe. Management Decision, 54(8), 1966-1985. https://doi.org/10.1108/MD-07-2015-0294

Maksimovic, V., \& Phillips, G. (1997). Asset efficiency and reallocation decisions of bankrupt firms. Working paper, University of Maryland, Maryland.

Masa, C.I., Iturrioz, J., \& Martín, S. (2016). Aspectos determinantes del fracaso empresarial: efecto de la proyección social de las sociedades cooperativas frente a otras formas jurídicas. Revista de Economía Pública, Social y Cooperativa, 88, 93-125.

Mensah, Y.H. (1984). An examination of the stationarity of multivariate bankruptcy prediction models: a methodological study. Journal of Accounting Research, 22(1), 380-395.

Miranda, M.E., De la Torre, J.M., \& Martínez, I.R. (2008). Análisis de sensibilidad temporal en los modelos de predicción de insolvencia: Una aplicación a las PYMES industriales. Revista Española de Financiación y Contabilidad, 37(137), 85-111.

Momparler, A., Carmona, P., \& Climent, F. (2016). Banking failure prediction: a boosting classification tree approach. Revista Española de Financiación y Contabilidad, 45(1), 63-91.

Ohlson, J.A. (1980). Financial ratios and the probabilistic prediction of bankruptcy. Journal of Accounting Research, 18(1), 109-131

Opler, T., \& Titman, S. (1994). Financial distress and corporate performance. The Journal of Finance, 49(3), 1015-1039. 
Petria, N. (2016). Financial stability and concentration: evidence from emerging Europe. Transformations in Business and Economics, 15, 376-395.

Platt, H., \& Platt, M. (1990). Development of a class of stable predictive variables: the case of bankruptcy prediction. Journal of Business, Finance and Accounting, 17(1), 31-51.

Platt, H., \& Platt, M. (1991). A note on the use of industry-relative ratios in bankruptcy prediction. Journal of Banking and Finance, 15(8), 1183-1194.

Pozuelo, J., Labatut, G., \& Veres, E. (2013). Validez de la información financiera en los procesos de insolvencia. Un estudio de la pequeña empresa española. Cuadernos de Economía y Dirección de la Empresa, 16(1), 29-40.

Rodríguez-López, M., Piñeiro, C., \& de Llano, P. (2014). Determinación del riesgo de fracaso financiero mediante la utilización de modelos paramétricos, de inteligencia artificial, y de información de auditoría. Estudios de economía, 41(2), 187-217.

Rodríguez-Masero, N., \& López-Manjón, J.D. (2016). El flujo de caja como determinante de la estructura financiera de las empresas españolas. Un análisis en tiempos de crisis. Revista de Métodos Cuantitativos para la Economía y la Empresa, 21, 141-159.

Rumler, F., \& Waschiczek, W. (2016). Have changes in the financial structure affected bank profitability? Evidence for Austria. The European Journal of Finance, 22(10), 803-824.

Serrano, C., \& Martín de Brio, B. (1993). Predicción de la quiebra bancaria mediante redes neuronales artificiales. Revista Española de Financiación y Contabilidad, 23(74), 153-176.

Shleifer, A., \& Vishny, R. (1992). Liquidation values and debt capacity: A market equilibrium approach. Journal of Finance, 47, 1343-1366.

Soedarmono, W., Machrouh, F., \& Tarazi, A. (2013). Bank competition, crisis and risk taking: evidence from emerging markets in Asia. Journal of International Financial Markets Institutions \& Money, $13,196-221$.

Somoza, A. (2001). La consideración de factores cualitativos, macroeconómicos y sectoriales en los modelos de predicción de la insolvencia empresarial: Su aplicación al sector textil y confección de Barcelona (1994-1997). Papeles de Economía Española, 89, 402-426.

Van Hemmen, S. (1997). Crisis financiera de la PYME en la provincia de Barcelona: análisis de estados contables de suspensiones de pagos en el periodo 1993-1995. El modelo RMB. Barcelona: Marcial Pons Editores.

Zhang, L., Altman, E.I., \& Yen, J. (2010). Corporate financial distress diagnosis model and application in credit rating for listing firms in China. Frontiers of Computer Science in China, 4(2), 220-236. https://doi.org/ 10.1007/s11704-010-0505-5

Zhang, G.Y. (2013). Emerging from Chapter 11 Bankruptcy: is it good news or bad news for industry competitors? Financial Management, 39(4), 1719-1742. 